\title{
Trpv1 Reporter Mice Reveal Highly Restricted Brain Distribution and Functional Expression in Arteriolar Smooth Muscle Cells
}

\author{
Daniel J. Cavanaugh, ${ }^{1 *}$ Alexander T. Chesler, ${ }^{2,3 *}$ Alexander C. Jackson, ${ }^{3}$ Yaron M. Sigal, ${ }^{2,3}$ Hiroki Yamanaka, ${ }^{1}$ \\ Rebecca Grant, ${ }^{4}$ Dajan 0'Donnell, ${ }^{4}$ Roger A. Nicoll, ${ }^{3}$ Nirao M. Shah, ${ }^{1}$ David Julius,,${ }^{2,3}$ and Allan I. Basbaum ${ }^{1}$ \\ Departments of ${ }^{1}$ Anatomy, ${ }^{2}$ Physiology, and ${ }^{3}$ Cellular and Molecular Pharmacology, University of San Francisco, San Francisco, California 94158 , and \\ ${ }^{4}$ AstraZeneca R\&D Montreal, St. Laurent, Quebec H4S 1Z9, Canada
}

\begin{abstract}
The heat and capsaicin receptor, TRPV1, is required for the detection of painful heat by primary afferent pain fibers (nociceptors), but the extent to which functional TRPV1 channels are expressed in the CNS is debated. Because previous evidence is based primarily on indirect physiological responses to capsaicin, here we genetically modified the $\operatorname{Trpv} 1$ locus to reveal, with excellent sensitivity and specificity, the distribution of TRPV1 in all neuronal and non-neuronal tissues. In contrast to reports of widespread and robust expression in the CNS, we find that neuronal TRPV1 is primarily restricted to nociceptors in primary sensory ganglia, with minimal expression in a few discrete brain regions, most notably in a contiguous band of cells within and adjacent to the caudal hypothalamus. We confirm hypothalamic expression in the mouse using several complementary approaches, including in situ hybridization, calcium imaging, and electrophysiological recordings. Additional in situ hybridization experiments in rat, monkey, and human brain demonstrate that the restricted expression of TRPV1 in the CNS is conserved across species. Outside of the CNS, we find TRPV1 expression in a subset of arteriolar smooth muscle cells within thermoregulatory tissues. Here, capsaicin increases calcium uptake and induces vasoconstriction, an effect that likely counteracts the vasodilation produced by activation of neuronal TRPV1.
\end{abstract}

\section{Introduction}

TRPV1 is a nonselective cation channel that is activated by noxious heat, protons, the vanilloid compounds capsaicin (CAP) and resiniferatoxin (RTX), and membrane-derived lipids, including anandamide (Caterina et al., 1997; Caterina and Julius, 2001). Studies of $\operatorname{Trp} v 1$ knock-out mice demonstrated a critical contribution of TRPV1 to the cellular and behavioral responses to noxious heat (Caterina et al., 2000; Davis et al., 2000). Although expression of TRPV1 was originally reported to be restricted to primary afferent nociceptors of the dorsal root ganglia (DRGs), trigeminal ganglia (TG), and nodose ganglia (Szallasi et al., 1995; Caterina et al., 1997; Tominaga et al., 1998), subsequent studies argued for a much wider distribution, both in the CNS and in non-neuronal tissues.

Expression of TRPV1 in the CNS has been reported using a variety of methods, including pharmacological characterization (Steenland et al., 2006), immunohistochemistry (Toth et al.,

\footnotetext{
Received Dec. 10, 2010; revised Jan. 20, 2011; accepted Feb. 7, 2011.

This work was supported by National Institutes of Health (NIH) Grants NS14627 (A.I.B.), R01NS049488, DP10D006425 (N.M.S.), and R37NS047723 (D.J.), by support from the Pell Family Foundation to A.I.B., and by National Institute of Mental Health (NIMH) grants to R.A.N. A.T.C. was supported by an NIH postdoctoral training grant from the UCSF Cardiovascular Research Institute. A.C.J. was supported by a Ruth L. Kirschstein National Research Service Award from NIMH (F32MH081430). We thank Cindy Yang for the IRES-mycCre construct and Nidhi Nuwal for help with rat hippocampal cultures. R.G. and D.0. are employees of AstraZeneca and declare that they have competing financial interest.

*D.J.C. and A.T.C. are joint first authors.

Correspondence should be addressed to Allan I. Basbaum at the above address. E-mail:allan.basbaum@ucsf.edu. DOI:10.1523/JNEUROSCI.6451-10.2011

Copyright $\odot 2011$ the authors $\quad 0270-6474 / 11 / 315067-11 \$ 15.00 / 0$
}

2005; Cristino et al., 2006), in situ hybridization (Mezey et al., 2000), radioligand binding (Acs et al., 1996; Roberts et al., 2004), and reverse transcription (RT)-PCR (Mezey et al., 2000). Despite this abundance of studies, the existence of TRPV1 in the brain remains a controversial topic, mainly because the extent and localization of TRPV1 varies considerably among studies, even those using very similar assays. For example, RTX binding studies reported results ranging from a lack of binding in the CNS (Szallasi et al., 1995) to widespread binding throughout the brain (Roberts et al., 2004). In part, the lack of consensus reflects the limitations of traditional approaches to determining gene expression, including variable sensitivity, poor signal-to-noise, and lack of specificity.

There is also controversy as to the functional contribution of TRPV1 in the CNS. For example, several groups reported alterations in hippocampal synaptic function in $\operatorname{Trp} v 1$ knock-out mice (Marsch et al., 2007; Gibson et al., 2008). However, these reports did not provide anatomical or biophysical evidence of TRPV1 expression in these cells. Furthermore, other groups found no effect of TRPV1 agonists on hippocampal synaptic function (Kofalvi et al., 2006; Benninger et al., 2008). These results illustrate the importance of definitively resolving the distribution of TRPV1. This is especially true because TRPV1 expression in the CNS has important implications for the potential side effects of TRPV1 agonists and antagonists being developed for the treatment of chronic pain.

Here we used gene targeting to modify the $\operatorname{Trpv} 1$ genetic locus and generated two lines of reporter mice, which allow for a highly 
sensitive readout of TRPV1 expression patterns. Consistent with our early reports (Tominaga et al., 1998), we demonstrate robust expression of TRPV1 in primary afferent neurons. However, with the exception of very low-level expression in a few discrete brain areas, most notably within and adjacent to the caudal hypothalamus, we could not confirm previous findings of a widespread TRPV1 distribution in the CNS. Calcium imaging, whole-cell recording, and in situ hybridization experiments demonstrated that the expression patterns revealed in the reporter mice reflected functional TRPV1 expression that is conserved across multiple mammalian species. Finally, the sensitivity and cellular resolution of our genetic marking strategy revealed functional TRPV1 expression in a subset of arteriolar smooth muscle cells (SMCs) in thermoregulatory tissues.

\section{Materials and Methods}

Animals and injections

Animal experiments were approved by the Institutional Animal Care and Use Committee and conducted in accordance with the National Institutes of Health Guide for the Care and Use of Laboratory Animals and the recommendations of the International Association for the Study of Pain.

A genomic clone containing the last exon of the Trpv1 gene (Wellcome Trust Sanger Institute; Geneservice, Ltd.) was used to generate a TRPV1targeting vector. We used site-directed mutagenesis to engineer an AscI site 3 bp downstream of the TRPV 1 stop codon, and constructs containing IRES-PLAP-IRES-nlacZ (TRPV1 ${ }^{\text {PLAP-nlacZ }}$ mice) or IRES-mycCre (TRPV1 ${ }^{\mathrm{Cre}}$ mice) were inserted into this targeting vector. Homologous recombinant embryonic stem cell clones were used in blastocyst injections to obtain chimeric mice. R26R-lacZ (Soriano, 1999), R26R-EYFP (Srinivas et al., 2001), and Trpv1 knock-out mice (Caterina et al., 2000) were described previously.

Intrathecal injections were performed as described previously (Cavanaugh et al., 2009). For RTX injections, mice were anesthetized with 1.5\% isoflurane and injected subcutaneously with escalating doses of RTX on consecutive days $(30,70,100$, and $200 \mathrm{mg} / \mathrm{ml})$, followed $7 \mathrm{~d}$ later with 200 $\mathrm{mg} / \mathrm{ml}$. Histology was performed 7-10 d after this final RTX injection.

\section{Placental alkaline phosphatase and lacZ detection}

Adult mice (6-8 weeks old) were perfused with $10 \mathrm{ml}$ of HEPES-buffered saline followed by $20 \mathrm{ml}$ of ice-cold $3.7 \%$ formaldehyde. Brain, spinal cord (SC), peripheral tissue, DRGs, and TG were dissected out, postfixed 3-4 h [for placental alkaline phosphatase (PLAP) staining] or $1.5 \mathrm{~h}$ [for nuclear lacZ (nlacZ) staining] at $4^{\circ} \mathrm{C}$, and cryoprotected overnight in $30 \%$ sucrose. For brain and SC, $40-80 \mu \mathrm{m}$ sections were processed as free-floating sections. For DRGs, TG, and tongue, $14 \mu \mathrm{m}$ cryostat sections were processed on slides. Ear, dura, and cremaster muscle were processed as whole mounts. PLAP and nlacZ staining was performed as described previously (Shah et al., 2004).

\section{Immunohistochemistry}

After nlacZ histochemistry, tissue was processed for immunohistochemistry as described previously (Tominaga et al., 1998). Primary antisera were as follows: guinea pig anti-TRPV1 [1:1000; Julius Laboratory, University of California at San Francisco (UCSF), San Francisco, CA], mouse anti-reelin (1:500; Millipore), and mouse anti-smooth muscle actin (SMA; 1:800; Sigma).

\section{$R T-P C R$}

Adult mice were perfused with $10 \mathrm{ml}$ of PBS followed by $10 \mathrm{ml}$ of RNA later (Ambion). TG, liver, bladder, and cremaster were dissected out and placed in RNA later on ice. For brain regions, $500 \mu \mathrm{m}$ brain sections were cut with a McIlwain Tissue Chopper into ice-cold PBS, and brain regions were microdissected out with sharp tissue forceps and put into RNA later on ice. To avoid contamination, separate forceps were used for dissection of each tissue/brain region.

RNA isolation was performed with TRIzol reagent (Sigma) according to the manufacturer's specifications. One microgram of each RNA was reverse transcribed with the SuperScript II Reverse Strand Synthesis System (Invit- rogen) using an oligo(dT) primer. Control reactions omitted reverse transcriptase. PCR amplification $\left(94^{\circ} \mathrm{C}\right.$ for $5 \mathrm{~min} ; 35$ cycles of $94^{\circ} \mathrm{C}$ for $30 \mathrm{~s}, 58^{\circ} \mathrm{C}$ for $30 \mathrm{~s}, 72^{\circ} \mathrm{C}$ for $1 \mathrm{~min} ; 72^{\circ} \mathrm{C}$ for $10 \mathrm{~min}$ ) was performed with $1 \mu \mathrm{lof} \mathrm{cDNA}$ using the following primer pair: $5^{\prime}$-gtttgtggacagctacagtg- $3^{\prime}$ and $5^{\prime}$ gaagccacatactccttgcg- $3^{\prime}$. Control PCR amplification $\left(94^{\circ} \mathrm{C}\right.$ for $5 \mathrm{~min} ; 25 \mathrm{cy}$ cles of $94^{\circ} \mathrm{C}$ for $30 \mathrm{~s}, 58^{\circ} \mathrm{C}$ for $30 \mathrm{~s}, 72^{\circ} \mathrm{C}$ for $1 \mathrm{~min} ; 72^{\circ} \mathrm{C}$ for $10 \mathrm{~min}$ ) was performed with a glyceraldehyde 3-phosphate dehydrogenase (GAPDH) primer pair $\left(5^{\prime}\right.$-accacagtccatgccatcac- $3^{\prime}$ and $5^{\prime}$-tccaccaccctgttgctgta- $\left.3^{\prime}\right)$ to ensure cDNA integrity. Amplification products were visualized on a $1 \%$ agarose gel with ethidium bromide and sequenced to confirm identity.

\section{Mouse in situ hybridization}

For in situ hybridization histochemistry (ISHH), mice were killed by decapitation under deep anesthesia. Brain and L4/5 DRGs were dissected out, rapidly frozen in powdered dry ice, and cut on a cryostat ( $5 \mu \mathrm{m}$ for DRG and $10 \mu \mathrm{m}$ for brain). Sections were thaw mounted onto slides and fixed in $4 \%$ formaldehyde, $\mathrm{pH} 7.4$, for $20 \mathrm{~min}$. ISSH was performed as described previously (Kobayashi et al., 2005) with an ${ }^{35}$ S-labeled cRNA probe directed against bases 1155-1908 of the full-length TRPV1 cDNA (antisense or sense; $1 \times 10^{7} \mathrm{cpm} / \mathrm{ml}$ ). For autoradiography, sections were coated with Kodak Nuclear Track Emulsion Type NTB (Carestream Health) diluted 1:1 with distilled water at $45^{\circ} \mathrm{C}$ and exposed for 2 months in lighttight boxes at $4^{\circ} \mathrm{C}$. After development in D-19 (Carestream Health) and fixation in $24 \%$ sodium thiosulfate, the sections were stained with hematoxylin-eosin (H\&E), air dried, cleared in xylene, and coverslipped.

For combined immunohistochemistry with ISHH, mice were deeply anesthetized with sodium pentobarbital and perfused transcardially with $20 \mathrm{ml}$ of phosphate buffer (PB), followed by $50 \mathrm{ml}$ of $4 \%$ formaldehyde. DRGs were dissected out and postfixed in the same fixative at $4^{\circ} \mathrm{C}$ overnight, followed by immersion in $20 \%$ sucrose in $\mathrm{PB}$ at $4^{\circ} \mathrm{C}$ for $3 \mathrm{~d}$. Tissue was frozen in powdered dry ice and cut on a cryostat at a $5 \mu \mathrm{m}$ thickness. Sections were preincubated in TBS containing 5\% normal goat serum (NGS) for $30 \mathrm{~min}$, followed by incubation in guinea pig anti-TRPV1 ( $1: 1000$; Julius Laboratory, UCSF) in TBS containing $5 \%$ NGS for $24 \mathrm{~h}$ at $4^{\circ} \mathrm{C}$, washed in TBS, and processed for DAB immunohistochemistry as described previously (Tominaga et al., 1998). Sections were then fixed in $4 \%$ formaldehyde for $5 \mathrm{~min}$ and immediately processed for ISHH, as described above, but emulsion was stopped after 3 weeks.

\section{Rat, monkey, and human in situ hybridization}

Frozen human tissues (with postmortem delay of $7 \mathrm{~h}$ ) were acquired from the Brain and Tissue Bank for Developmental Disorders (University of Maryland, Baltimore, MD). Monkey tissues were obtained from an adult male Macaca fascicularis (ITR Laboratories Canada). Rat brain was acquired from adult male Sprague Dawley rats (Charles River).

Brains were rapidly dissected, snap frozen at $-40^{\circ} \mathrm{C}$ in isopentane for $20 \mathrm{~s}$, and stored at $-80^{\circ} \mathrm{C}$. Frozen tissues were cryosectioned at $14 \mu \mathrm{m}$ and mounted onto Superfrost Plus slides (VWR Canada). Slides were stored at $-80^{\circ} \mathrm{C}$ until further use.

Species-specific antisense riboprobes for rat, monkey, and human TRPV1 were transcribed in vitro using SP6 RNA polymerase (Promega) and radiolabeled with ${ }^{35} \mathrm{~S}-\mathrm{UTP}$ and ${ }^{35} \mathrm{~S}$-CTP $(\sim 800 \mathrm{Ci} / \mathrm{mmol}$; GE Healthcare). After transcription, the TRPV1 DNA templates were digested with DNase I (Promega) and subsequently purified using G-50 Sepharose microspin columns (GE Healthcare). The quality of labeled riboprobes was verified by polyacrylamide-urea gel electrophoresis and scintillation counting.

For ISHH, tissue sections were fixed with $4 \%$ paraformaldehyde, rinsed three times in $2 \times$ SSC, equilibrated in $0.1 \mathrm{M}$ triethanolamine (TEA), and treated with $0.25 \%$ acetic anhydride in $0.1 \mathrm{~m}$ TEA. After a rinse in $2 \times$ SSC and dehydration through an ethanol series (50-100\%), hybridization was performed in buffer containing 75\% formamide (Sigma), 600 mm NaCl, 10 mm Tris-HCl, pH 7.5, 1 mm EDTA, $1 \times$ Denhardt's solution (Sigma), $50 \mu \mathrm{g} / \mathrm{ml}$ denatured salmon sperm DNA (Sigma), 10\% dextran sulfate (Sigma), $20 \mathrm{~mm}$ dithiothreitol, and $\left[{ }^{35} \mathrm{~S}\right]$ labeled cRNA probe $\left(20 \times 10^{6} \mathrm{cpm} / \mathrm{ml}\right)$ at $55^{\circ} \mathrm{C}$ overnight in chambers humidified with $75 \%$ formamide. After hybridization, slides were rinsed twice in $2 \times$ SSC at room temperature, treated with $20 \mu \mathrm{g} / \mathrm{ml} \mathrm{RNase} \mathrm{IA} \mathrm{in}$ RNase buffer (25 mm NaCl, 5 mm Tris-HCl, pH 7.5, 0.5 mм EDTA, pH 
A

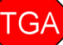

\begin{tabular}{|l|l|l|l|l|} 
TRPV1 & I & PLAP & I & nlacZ \\
\hline
\end{tabular}

B
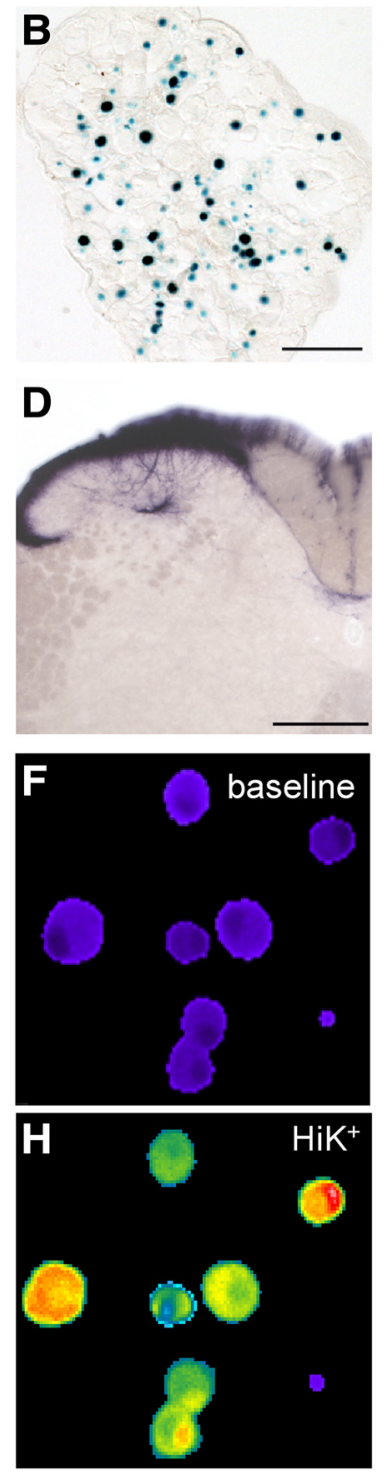

J

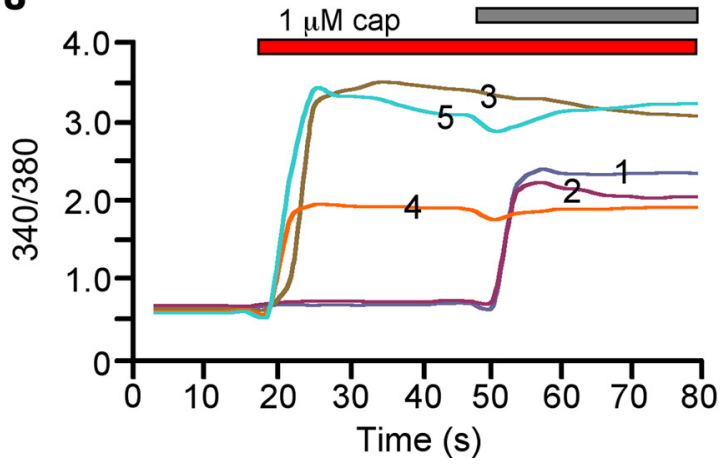

Figure 1. Primary afferent expression of reporter molecules in TRPV1 ${ }^{\text {PLAP-nlacZ }}$ mice. $A$, Schematic showing the Trpv 1 locus of TRPV $1{ }^{\text {PLAP-nlacZ }}$ mice. $\boldsymbol{B}$, nlacZ is present in nuclei of DRG neurons. C, PLAP is present both in cell bodies (arrowheads) and axonal processes (arrows) of DRG neurons. D, PLAP staining in primary afferent terminals in the SC dorsal horn. $\boldsymbol{E}$, nlacZ staining (magenta) in the DRG section shows near-complete overlap with TRPV1 immunoreactivity (green). $\boldsymbol{F}-\boldsymbol{H}$, Cultured adult DRG neurons were imaged with Fura-2-AM dye at baseline $(\boldsymbol{F})$ and following stimulation with $1 \mu \mathrm{M} C \mathrm{CAP}(\boldsymbol{G})$ and $\mathrm{HiK}(\boldsymbol{H})$.
8.0) for $45 \mathrm{~min}$ at $37^{\circ} \mathrm{C}$, and washed to a final stringency of $0.1 \times \mathrm{SSC}$ at $70^{\circ} \mathrm{C}$. Sections were then dehydrated and exposed to Kodak Biomax MR-2 film. After exposure to film, the slides were dipped in Kodak NTB2 emulsion and exposed for 8 weeks at $4^{\circ} \mathrm{C}$ before development and counterstaining with $\mathrm{H} \& \mathrm{E}$. Film autoradiograms were digitized with a highresolution Microimager digital camera (Xillix) via the MCID image analysis system (Imaging Research). Bright- and dark-field photomicrographs of emulsion-dipped tissue sections were captured using a microscope (DMRBE/DM 4000B; Leica) equipped with a DFC490 digital camera (Leica). Digital images were transferred to Adobe Photoshop 7.0 for minimal image processing.

\section{DRG calcium imaging}

DRG neurons were isolated from 6-week-old mice, dissociated, and subjected to ratiometric calcium imaging the next day as described previously (Caterina et al., 2000). Cells were stimulated with $1 \mu \mathrm{M}$ CAP, followed by $150 \mathrm{~mm} \mathrm{~K}^{+}$(HiK) Ringer's solution, fixed, and stained for nlacZ histochemistry. All neurons that responded to HiK solution were included for analysis.

Hypothalamic slice and acutely dissociated neuron preparation, $\mathrm{Ca}^{2+}$ imaging, and whole-cell recording

Two hundred micrometer coronal slices of caudal hypothalamus were cut from TRPV1 ${ }^{\text {Cre }} /$ R26R-EYFP mice [age, postnatal day 21 (P21) to P26] using a DTK-100 Microslicer (Ted Pella). Slices were cut in an ice-cold, high-sucrose solution consisting of (in $\mathrm{mm}$ ) $87 \mathrm{NaCl}, 1.25$ $\mathrm{NaH}_{2} \mathrm{PO}_{4}, 25 \mathrm{NaHCO}_{3}, 2.5 \mathrm{KCl}, 0.5 \mathrm{CaCl}_{2}, 7 \mathrm{MgCl}_{2}, 25$ glucose, and 75 sucrose, saturated with $95 \% \mathrm{O}_{2} / 5 \% \mathrm{CO}_{2}$. Freshly cut slices were placed in an incubating chamber containing artificial CSF (ACSF; in mM: 125 $\mathrm{NaCl}, 2.5 \mathrm{KCl}, 25 \mathrm{NaHCO}_{3}, 1.25 \mathrm{Na}_{2} \mathrm{PO}_{4}, 15$ glucose, $2 \mathrm{CaCl}_{2}$, and 1 $\mathrm{MgCl}_{2}$ ), saturated with $95 \% \mathrm{O}_{2} / 5 \% \mathrm{CO}_{2}$, and allowed to recover at $35^{\circ} \mathrm{C}$ for $\sim 30 \mathrm{~min}$ and then $30 \mathrm{~min}$ to $1 \mathrm{~h}$ at room temperature.

$\mathrm{Ca}^{2+}$ imaging. Slices were loaded with $10 \mu \mathrm{m}$ Fura-2-AM (Invitrogen) and $0.2 \%$ pluronic acid at $22-25^{\circ} \mathrm{C}$ for $60 \mathrm{~min}$ in ACSF, saturated with $95 \%$ $\mathrm{O}_{2} / 5 \% \mathrm{CO}_{2}$. For imaging, slices were perfused with ACSF, saturated with $95 \% \mathrm{O}_{2} / 5 \% \mathrm{CO}_{2}$ and containing TTX (500 nM), picrotoxin (100 $\left.\mu \mathrm{M}\right), \mathrm{APV}$ $(100 \mu \mathrm{M})$, and 2,3-dioxo-6-nitro-1,2,3,4-tetrahydrobenzo[f] quinoxaline-7sulfonoamide (NBQX; $10 \mu \mathrm{M})$. CAP $(1-10 \mu \mathrm{M})$ and HiK solution $(140 \mathrm{~mm})$ were added to the same supplemented ACSF solution and applied using a bath perfusion system. Image acquisition and analysis were performed as detailed above for DRG neurons.

Whole-cell recording. After recovery, slices were transferred to a submersion chamber on an upright Olympus BX51 microscope and perfused with ACSF, saturated with $95 \% \mathrm{O}_{2} / 5 \% \mathrm{CO}_{2}$. Enhanced yellow fluorescent protein-positive (EYFP + ) cells in the supramammillary nucleus (SuM) and posterior hypothalamus were identified by epifluorescence microscopy and recorded with 3-5 $\mathrm{M} \Omega$ borosilicate glass pipettes, filled with an internal solution consisting of (in mM) $140 \mathrm{CsMeSO}_{3}, 10$ HEPES, 10 EGTA, $2 \mathrm{NaCl}, 2 \mathrm{Mg}$-ATP, 1 QX-314, 5 TEA-Cl, and $1 \mathrm{CaCl}_{2}$, $\mathrm{pH}$ 7.3. After the formation of a seal and achieving whole-cell configuration, membrane potential was held in voltage-clamp mode at $-60 \mathrm{mV}$, and stable baseline holding current was established. The bath solution was then switched to a control ACSF solution containing TTX (500 nM), picrotoxin $(100 \mu \mathrm{M})$, APV $(100 \mu \mathrm{M})$, and NBQX $(10 \mu \mathrm{M})$ for several minutes, followed by ACSF containing $10 \mu \mathrm{M}$ CAP for $\sim 5 \mathrm{~min}$, and then back to ACSF to wash out responses. In some cases, $20 \mu \mathrm{M}$ Ruthenium Red (RR; final concentration) was added directly to the bath.

$\mathrm{Ca}^{2+}$ imaging of acutely dissociated cells. Coronal slices of caudal hypothalamus were cut as described and transferred to a dissociation solution consisting of $2.5 \mathrm{mg} / \mathrm{ml}$ protease XXIII (Sigma) dissolved in the sucrose cutting solution. Slices were incubated at $35^{\circ} \mathrm{C}$ for $10 \mathrm{~min}$, rinsed several times in cold sucrose solution, and placed in cold $\left(4^{\circ} \mathrm{C}\right)$ sucrose solution containing $1 \mathrm{mg} / \mathrm{ml}$ trypsin inhibitor (Sigma) and $1 \mathrm{mg} / \mathrm{ml}$ bovine serum albumin (Sigma). The SuM was isolated with iridectomy scissors and

$\boldsymbol{I}$, nlacZ staining in these cells. $\boldsymbol{J}$, The $340 / 380$ ratios of cells as numbered in $I$. Scale bars: $\boldsymbol{B}, \boldsymbol{C}, \boldsymbol{E}$, I, $100 \mu \mathrm{m} ; \mathbf{D}, 200 \mu \mathrm{m}$. 

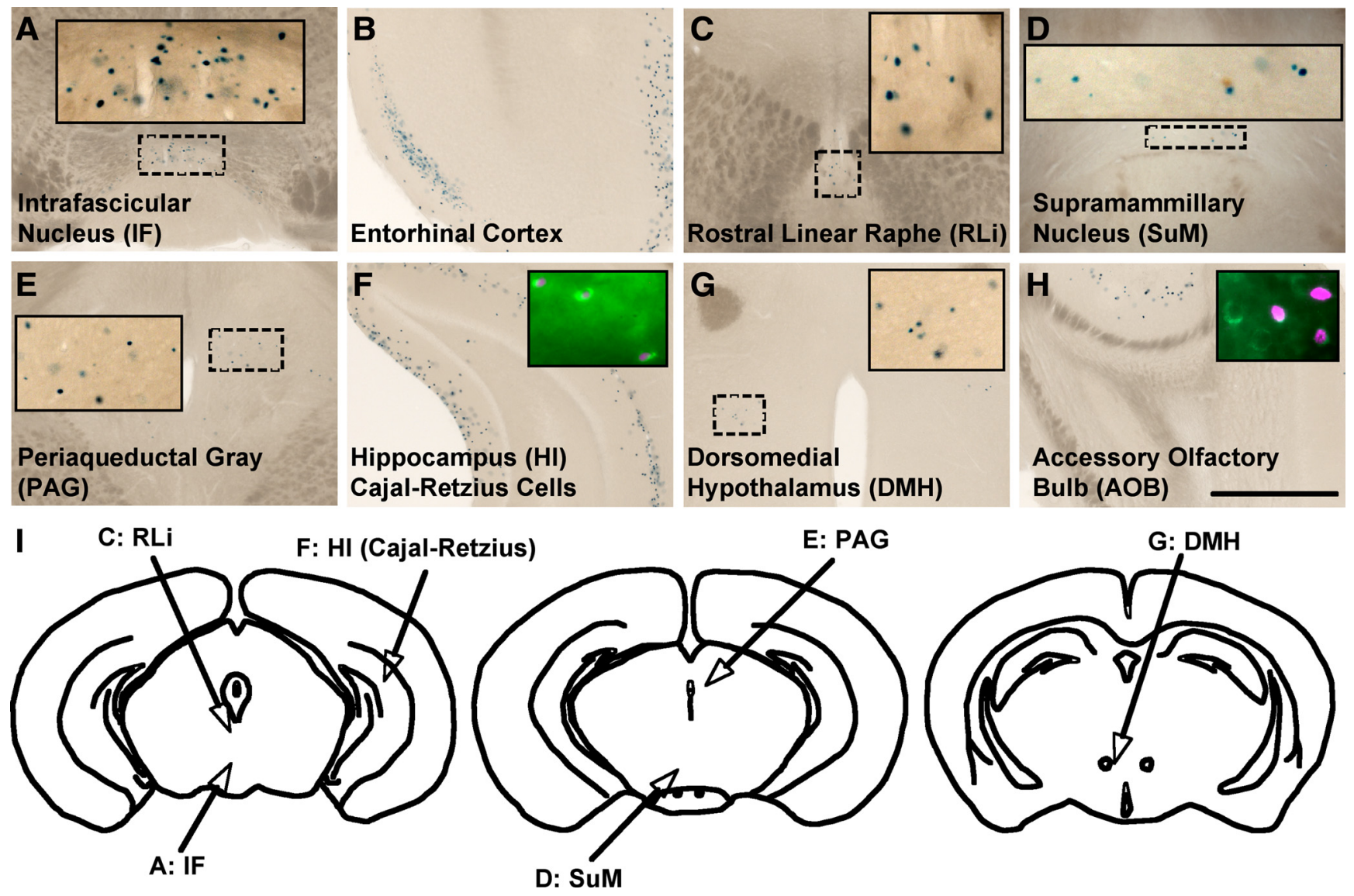

Figure 2. nlacZ staining in coronal sections of TRPV1 ${ }^{\text {PLAP-nlacZ }}$ mice. $\boldsymbol{A}-\boldsymbol{H}$, We observed sparse nlacZ expression in the IF $(\boldsymbol{A})$, entorhinal cortex $(\boldsymbol{B})$, RLi $(\boldsymbol{C})$, SuM $(\boldsymbol{D})$, periaqueductal gray (PAG; $\left.\boldsymbol{E}\right)$, Cajal-Retzius cells of the hippocampus (HI; $\boldsymbol{F}$, DMH $(\boldsymbol{G})$, and $\mathrm{AOB}(\boldsymbol{H})$. Insets in $\boldsymbol{A}, \boldsymbol{C}, \boldsymbol{D}, \boldsymbol{E}$, and $\boldsymbol{G}$ are magnified images of dashed regions. Insets in $\boldsymbol{F}$ and $\boldsymbol{H}$ show sections processed for nlacZ (magenta) and stained for reelin immunoreactivity (green). $I$, Outlines of coronal brains illustrating the nlacZ + areas of the rostral midbrain and caudal hypothalamus. Scale bar, $200 \mu \mathrm{m}$.

gently triturated using a series of fine-bore Pasteur pipettes. Dissociated neurons were imaged as described for DRG neurons.

\section{Hippocampal slice imaging}

Two hundred micrometer coronal slices of P19 hippocampus were cut from wild-type mice as detailed above for caudal hypothalamic slices. Slices were loaded with $100 \mu \mathrm{m}$ Fura-2-AM (Invitrogen) and $0.2 \%$ pluronic acid at $22-25^{\circ} \mathrm{C}$ for $60 \mathrm{~min}$ in ACSF, saturated with $95 \% \mathrm{O}_{2} / 5 \%$ $\mathrm{CO}_{2}$, and calcium imaging was performed as detailed above for hypothalamic slices.

\section{Arteriole calcium imaging}

Third-order arterioles were dissected out of ears, bathed in ice-cold physiological salt solution (in mM: $137 \mathrm{NaCl}, 5.6 \mathrm{KCl}, 1 \mathrm{MgCl}_{2}, 0.42$ $\mathrm{Na}_{2} \mathrm{HPO}_{4}, 0.44 \mathrm{NaH}_{2} \mathrm{PO}_{4}, 4.2 \mathrm{NaHCO}_{3}, 10$ HEPES, and $1 \mathrm{mg} / \mathrm{ml} \mathrm{BSA}$, $\mathrm{pH}$ 7.4), cut into $\sim 2 \mathrm{~mm}$ pieces, and cultured in poly-D-lysine-coated wells in low-glucose DMEM with 10\% fetal bovine serum and penicillinstreptomycin. The next day, arterioles were subjected to ratiometric calcium imaging as described above. Cells were stimulated with 1 and $10 \mu \mathrm{M}$ CAP, followed by $10 \mu \mathrm{M} R$ R to block responses, and finally with HiK+ Ringer's solution.

\section{Results}

\section{TRPV1 reporter mice}

We used gene targeting to create a line of mice (TRPV1 ${ }^{\text {PLAP-nlacZ }}$ ) in which PLAP and nlacZ are expressed under the control of the TRPV1 promoter. We inserted an IRES-PLAP-IRES-nlacZ cassette immediately $3^{\prime}$ of the TRPV1 stop codon, which permits the transcription and translation of PLAP and nlacZ in cells expressing TRPV1, without disrupting the Trpv1 coding region (Fig. $1 A$ ). In addition to providing a very sensitive detection method, background levels of PLAP and nlacZ are negligible in the mouse (Shah et al., 2004), which allows for discrete localization of TRPV1.

As expected, TRPV1 ${ }^{\text {PLAP-nlacZ }}$ mice robustly expressed nlacZ in nuclei of primary afferent neurons of the DRG and TG (Fig. $1 B$ ). PLAP histochemistry labeled both cell bodies and axonal processes in the DRG (Fig. 1C), as well as primary afferent terminals of the SC dorsal horn (Fig. 1D). The SC staining was eliminated by intrathecal injection of high-dose CAP (data not shown), which selectively destroys TRPV1 fibers (Cavanaugh et al., 2009), indicating that the PLAP staining indeed arises from TRPV1 nociceptors.

nlacZ specifically marks CAP-responsive, TRPV1+ DRG neurons

To establish the specificity of nlacZ expression for TRPV1 neurons, we investigated the CAP responsiveness of nlac $Z+D R G$ neurons cultured from adult TRPV1 ${ }^{\text {PLAP-nlacZ }}$ mice, using livecell calcium imaging (Fig. $1 F-J$ ). Importantly, we found that $>99 \%$ of nlacZ + neurons responded to $1 \mu \mathrm{M}$ CAP and $>90 \%$ of CAP-responsive neurons were nlacZ $+(n=568)$. We also compared the expression of nlacZ and TRPV1 in DRG sections (Fig. $1 E)$. Consistent with the calcium imaging results, we found that $>95 \%$ of TRPV1-immunoreactive neurons were nlac $Z+$. These results demonstrate that nlacZ histochemistry provides a sensitive and accurate correlate of functional TRPV1 expression, in vivo as well as in vitro. 

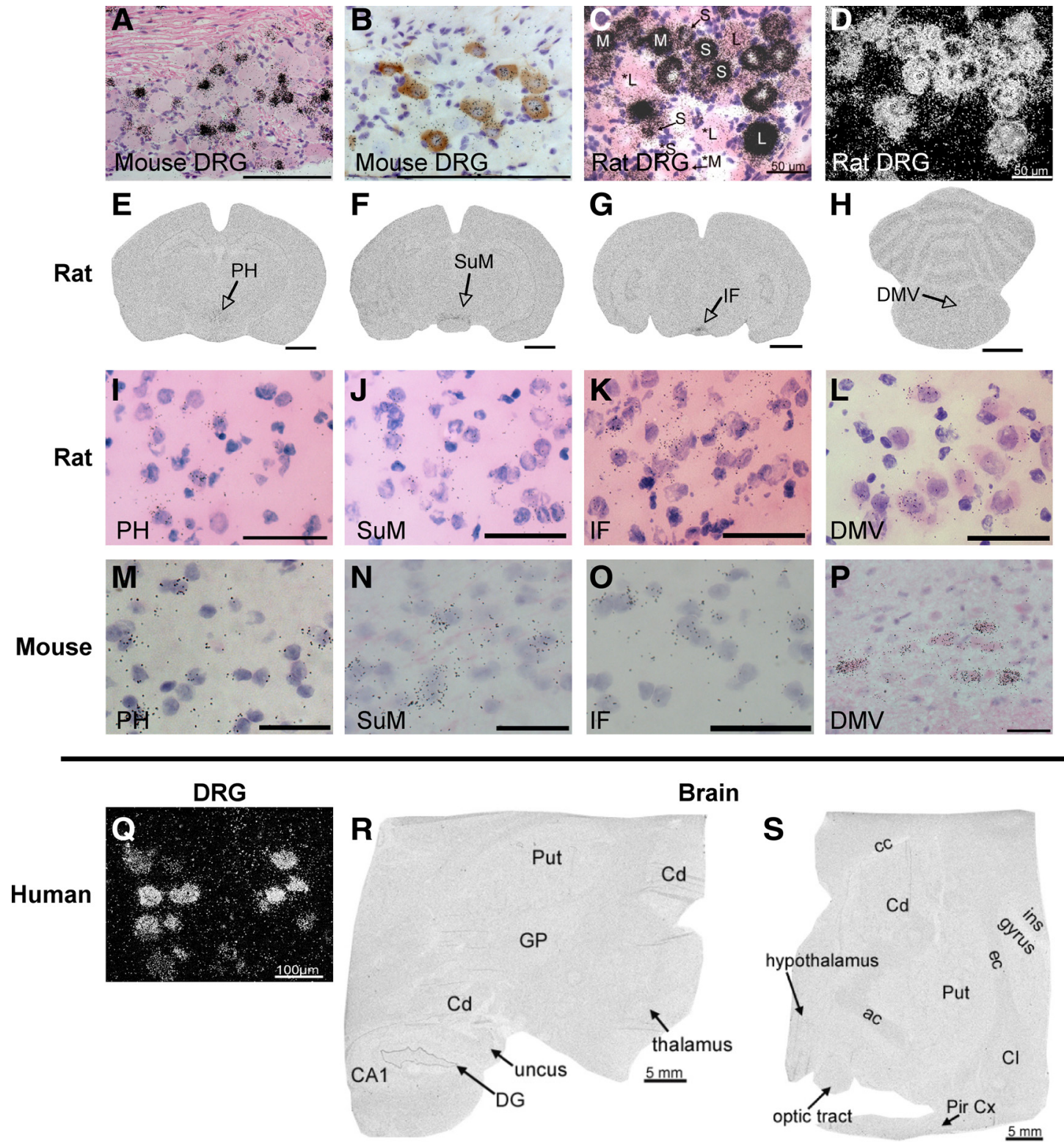

Figure 3. Radioactive in situ for TRPV1 in DRGs and brain of mouse, rat, and human. A, Bright-field image of radioactive in situ in mouse DRG, counterstained with H\&E. B, Double labeling with TRPV1 antibody (brown) and radioactive in situ probe (black) shows complete colocalization between the two in mouse DRG. C, Bright-field image of radioactive in situ in rat DRG, counterstained with H\&E. S, Small-diameter neurons; M, medium-diameter neurons; L, large-diameter neurons. Asterisks indicate negative cells. D, Dark-field image of radioactive in situ in rat DRG. E-H, Coronal sections of rat brain processed for radioactive TRPV1 in situ hybridization showing positive signals in PH (E), SuM (F), IF (G), and DMV (10th motor nucleus; $\boldsymbol{H})$. I-P, Close-up images of indicated regions are shown for rat $(\boldsymbol{I}-\boldsymbol{L})$ and mouse $(\boldsymbol{M}-\boldsymbol{P})$. $\mathbf{Q}$, Dark-field image of radioactive in situ signal in human DRG. $\boldsymbol{R}, \mathbf{S}$, Representative images of radioactive in situ in human brain sections, demonstrating complete lack of staining. ac, Anterior commissure; CA1, CA1 region of hippocampus; cc, corpus callosum; Cd, caudate; Cl, claustrum; DG, dentate gyrus; ec, external capsule; GP, globus pallidus; ins gyrus, insular gyrus; Pir CX, piriform cortex; Put, putamen. Scale bars: $\boldsymbol{A}, \boldsymbol{B}, \mathbf{Q}, 100 \mu \mathrm{m} ; \boldsymbol{C}, \boldsymbol{D}, \boldsymbol{I}-\boldsymbol{L}, 50 \mu \mathrm{m} ; \boldsymbol{E}-\boldsymbol{H}, 2 \mathrm{~mm} ; \boldsymbol{M}-\boldsymbol{P}, 25 \mu \mathrm{m} ; \boldsymbol{R}, \mathbf{S}, 5 \mathrm{~mm}$.

Highly restricted expression of TRPV1 in the adult brain We found no PLAP+ cell bodies in the brain of TRPV1 ${ }^{\text {PLAP-nlacZ }}$ mice. We did, however, find limited nlacZ expression in a few brain areas, primarily along midline structures of the rostral midbrain and caudal hypothalamus (Fig. 2). Prominent among these brain areas were the intrafascicular nucleus (IF) (Fig. 2A) and SuM (Fig. 2D), as well as the dorsomedial hypothalamus $(\mathrm{DMH})$ and posterior hypothalamus (PH) (Fig. 2G). We also detected scattered nlacZ+ cells in the entorhinal cortex (Fig. $2 B$ ), the rostral linear raphe nucleus (RLi) (Fig. 2C) and the periaqueductal gray (Fig. 2E). Finally, nlacZ expression marked a discrete subset of (nonpyramidal) hippocampal neurons (Fig. $2 F$ ) that colabeled for reelin, a marker of Cajal-Retzius cells (Fig. $2 F$, inset), as well as reelin + cells in the accessory olfactory bulb (AOB)
(Fig. $2 H$ ). It is likely that our failure to detect PLAP in these brain regions reflects the greater sensitivity of nlacZ versus PLAP histochemistry.

We used several complementary approaches to verify the expression pattern revealed in the Trpvl knock-in mice. We could not detect staining in any of these brain areas using TRPV1 antisera, most likely because TRPV1 is expressed at levels below the detection threshold of immunohistochemistry. Furthermore, with the exception of the caudal hypothalamus (which included the SuM and IF), we failed to detect TRPV1 mRNA by RT-PCR in any of the brain regions where we saw nlacZ expression (see Fig. $5 J)$. Finally, radioactive in situ confirmed the restricted expression suggested by the Trpv1 reporter mice, with positive signals in the IF, SuM, DMH, and PH (Fig. 3M-O). Together with the lack 
of PLAP staining, these results indicate that TRPV1 in the brain is limited to very low-level expression in a small subset of cells of a few discrete brain regions.

\section{Restricted expression of TRPV1 in CNS is conserved across species}

The distribution of TRPV1 in the DRG of the mouse differs from that of the rat (Woodbury et al., 2004), which suggests that brain expression patterns might also differ across species. To investigate this, we performed radioactive in situ hybridization in several species, including rat, monkey, and human. Importantly, using several different high-affinity probes directed against rat TRPV1, we found a near-identical pattern of CNS staining compared with that obtained in the mouse. Most notably, specific signals were found in caudal hypothalamic regions, including the $\mathrm{PH}, \mathrm{SuM}$, and IF (Fig. 3E-L). Positive signals were also found in the dorsal motor nucleus of the vagus (DMV), mesencephalic trigeminal nucleus, parabrachial nucleus, $\mathrm{RLi}$, and lateral hypothalamus of the rat (data not shown). In monkey (data not shown) and human brain sections (Fig. 3R-S), we could not detect any TRPV1+ signal; however, we did not have access to sections that included the areas of the caudal hypothalamus that had positive signals in rat and mouse. Nevertheless, the lack of signal in other brain areas, despite the strong specific signal in DRG neurons (Fig. 3Q), is consistent with the highly restricted pattern we observed in mouse and rat, thus demonstrating that this property is conserved across multiple mammalian species.

\section{Transient embryonic TRPV1 expression in the brain}

As this highly restricted CNS expression pattern contrasted with reports of widespread TRPV1 distribution, we created a second line of reporter mice (TRPV1 ${ }^{\mathrm{Cre}}$ mice), in which Cre recombinase is expressed under the control of the TRPV1 promoter (Fig. $4 A)$. Crosses of this line with Cre-dependent reporter lines provide a highly sensitive fate map of TRPV1 expression, which reveals all loci of TRPV1 expression, no matter how transient. When we crossed TRPV1 ${ }^{\text {Cre }}$ mice with the Rosa-lacZ reporter line (TRPV1 Cre/R26R-lacZ) (Soriano, 1999), we observed the expected pattern of DRG and SC staining (Fig. $4 B, C$ ).

Importantly, all the nlacZ+ brain areas in the TRPV1 ${ }^{\text {PLAP-nlacZ }}$ mice were also stained by lacZ in the TRPV1 ${ }^{\mathrm{Cre}} / \mathrm{R} 26 \mathrm{R}$-lacZ mice (Fig. $4 D-K$ ). The staining in TRPV1 ${ }^{\mathrm{Cre}} / \mathrm{R} 26 \mathrm{R}-\mathrm{lacZ}$ mice was more widespread than that in TRPV1 ${ }^{\text {PLAP-nlacZ }}$ mice, with the exception of the reelin + cells of the hippocampus and AOB, likely because expression of the Rosa locus is limited in these cells (data not shown). The more extensive labeling in the TRPV1 Cre/ R26R-lacZ mice compared with TRPV1 ${ }^{\text {PLAP-nlacZ }}$ shows that the cellular distribution of TRPV1 in these brain areas undergoes a developmental restriction. We additionally noted several regions in which expression is observed in the TRPV1 ${ }^{\mathrm{Cr}} / \mathrm{R} 26 \mathrm{R}$-lacZ mice, but not in the TRPV1 ${ }^{\text {PLAP-nlacZ }}$ mice (Fig. 5). These are likely areas where TRPV1 is transiently expressed during the embryonic or early postnatal periods. However, because only a few molecules of Cre are necessary to induce recombination, it is possible that some of these areas represent regions where TRPV1 is expressed at extremely low levels in the adult, below the detection threshold of the TRPV1 $1^{\text {PLAP-nlacZ }}$ mice. This could be the case for the DMV, where we observed in situ signals in both the mouse and rat despite a lack of staining in sections from TRPV1 ${ }^{\text {PLAP-nlacZ }}$ mice (Fig. $3 H, L, P$ ).

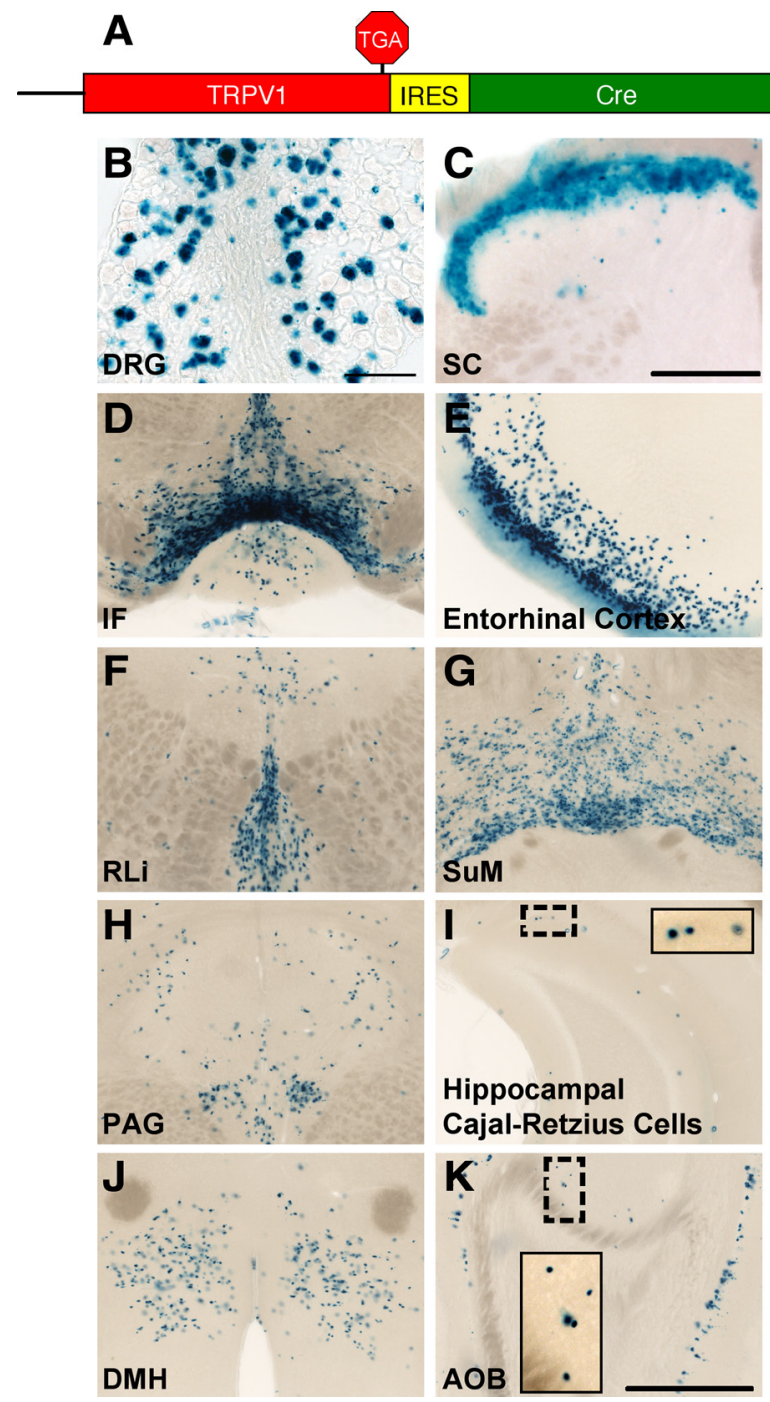

Figure 4. Brain lacZ staining in TRPV1 1 re /R26R-lacZ mice. $A$, Schematic showing the Trpv1 locus of TRPV1 ${ }^{\text {Cre }}$ mice. $\boldsymbol{B}, \boldsymbol{C}$, lacZ staining in DRG (B) and SC (C) of TRPV1 ${ }^{\text {Cre }} /$ R26R-lacZ mice. $\boldsymbol{D}-\boldsymbol{K}$, We observed lacZ + cells in the IF $(\boldsymbol{D})$, entorhinal cortex $(\boldsymbol{E})$, RLi $(\boldsymbol{F})$, SuM $(\boldsymbol{G})$, periaqueductal gray (PAG; $\boldsymbol{H})$, Cajal-Retzius cells of the hippocampus (HI; $\boldsymbol{l}), \mathrm{DMH}(\boldsymbol{J})$, and AOB (K). Insets are magnified images of dashed regions. Scale bars: $\boldsymbol{B}, 100 \mu \mathrm{m} ; \boldsymbol{C}-\boldsymbol{K}, 200 \mu \mathrm{m}$.

\section{Functional expression of TRPV1 in caudal hypothalamic nuclei}

As lacZ expression in the IF, SuM, DMH, and $\mathrm{PH}$ of reporter mice was confirmed by RT-PCR and radioactive in situ, we sought to validate functional TRPV1 expression in these brain areas using calcium imaging and whole-cell recordings in brain slices from TRPV1 ${ }^{\mathrm{Cre}}$ mice crossed to EYFP reporter mice (TRPV1 ${ }^{\mathrm{Cre}}$ / R26R-EYFP mice) (Srinivas et al., 2001). Importantly, EYFP staining in these mice was identical to lacZ expression in TRPV1 ${ }^{\text {Cre }}$ /R26R mice (data not shown).

We performed calcium imaging experiments in caudal hypothalamic neurons in intact slices (Fig. $6 A-D$ ) and acutely dissociated cells (Fig. $6 E-H$ ). We consistently observed calcium responses in EYFP + cells of hypothalamic slices in response to bath application of $10 \mu \mathrm{M} \mathrm{CAP}$, in the presence of the fast synaptic transmission blockers picrotoxin, NBQX, and APV and the voltage-gated sodium channel blocker TTX. In acutely dissociated cells, CAP elicited robust responses at doses as low as $100 \mathrm{~nm}$. CAP responses were blocked by preincubation with $10 \mu \mathrm{M} R \mathrm{R}$, a nonselective antagonist that blocks 


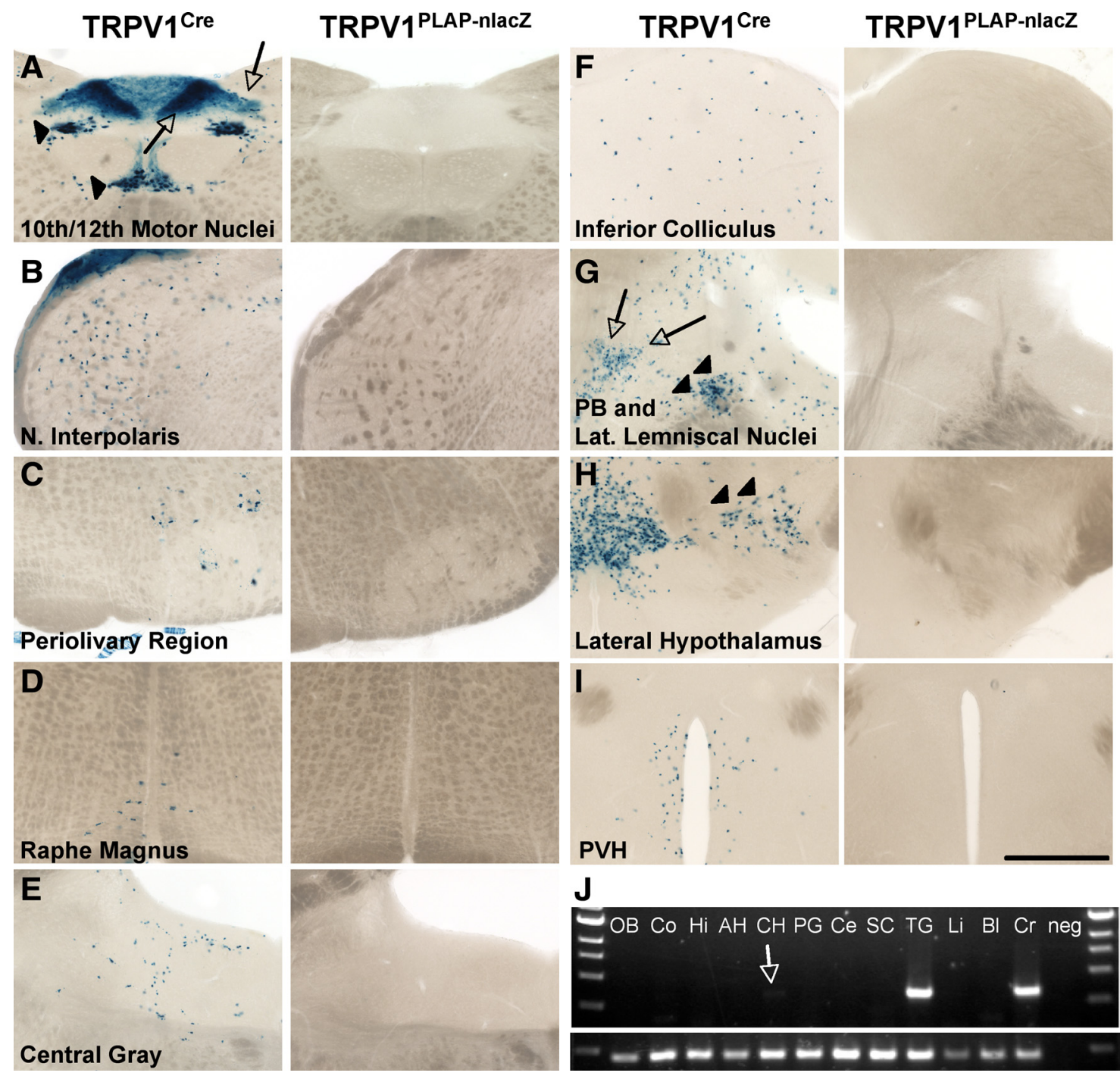

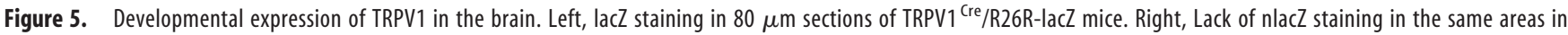
TRPV1 ${ }^{\text {PLAP-nlacZ }}$ mice, likely attributable to developmental expression that is extinguished in the adult. $\boldsymbol{A}-\boldsymbol{I}$, Regions include the 10th and 12th motor nuclei of the medulla ( $\boldsymbol{A}$ ) (arrowheads indicate cell body staining in 10th and 12th motor nuclei; arrows indicate axonal lacZ label in the area postrema and nucleus of the solitary tract), nucleus interpolaris (B), perivolivary region $(\boldsymbol{C})$, raphe magnus $(\boldsymbol{D})$, central gray region $(\boldsymbol{E})$, inferior colliculus $(\boldsymbol{F})$, parabrachial nucleus (PB; arrowheads) and nucleus of the lateral lemniscus (arrows) $(\boldsymbol{G})$, lateral hypothalamic nucleus ( $\boldsymbol{H}$, arrowheads), and paraventricular hypothalamic nucleus (PVH; $\boldsymbol{l})$. $\boldsymbol{J}, \mathrm{RT}$-PCR analysis of brain regions and peripheral tissues to detect presence of TRPV1 mRNA. Note the faint band in caudal hypothalamus lane (arrow). OB, Olfactory bulb; $\mathrm{C}$, cortex; $\mathrm{Hi}$, hippocampus; $\mathrm{AH}$, anterior hypothalamus; $\mathrm{CH}$, caudal hypothalamus; $\mathrm{PG}$, periaqueductal gray; Ce, cerebellum; Li, liver; BI, bladder; Cr, cremaster; neg, no cDNA. Scale bar, $500 \mu \mathrm{m}$.

many calcium-permeant ion channels including TRPV1 (Fig. $6 J$ ), and were absent in Trpv1 knock-out mice (data not shown). CAP-induced calcium increases were limited to EYFP + cells; $\sim 97 \%$ (30 of 31) of CAP-responsive cells were EYFP + . However, only $\sim 59 \%$ (30 of 51) of EYFP + cells tested were CAP responsive, consistent with a developmental downregulation of TRPV1.

Finally, we performed whole-cell patch-clamp recordings from acute hypothalamic slices, containing the SuM and $\mathrm{PH}$, prepared from P21-P26 TRPV1 ${ }^{\mathrm{Cre}} / \mathrm{R} 26 \mathrm{R}-\mathrm{EYFP}$ mice. We performed voltage-clamp recordings from visually identified EYFP + neurons, held at a membrane potential of $-60 \mathrm{mV}$, while bath applying $10 \mu \mathrm{M}$ CAP in the presence of TTX and synaptic blockers. We found that $\sim 53 \%$ (10 of 19) of EYFP+ neurons responded to CAP with inward current greater than $-5 \mathrm{pA}$; the average amplitude was $-52.9 \pm 14 \mathrm{pA}(n=10)$ (Fig. $6 K)$. CAP responses generally desensitized during application, slowly re- versed after washout, and could be blocked by RR (data not shown).

As an additional test of the accuracy and selectivity of our reporter mice, we performed calcium imaging experiments in regions of the hippocampus where others have argued for a functional contribution of TRPV1 (Marsch et al., 2007; Gibson et al., 2008, Chavez et al., 2010), but where we see no anatomical evidence for TRPV1 expression. In intact slices of the dentate gyrus, we never observed calcium increases in response to administration of $10 \mu \mathrm{M}$ CAP (Fig. $6 L-O$ ). We also failed to detect CAP responses in the CA1 region of the hippocampus (data not shown), although pyramidal cell loading in these preparations was suboptimal. However, we did not observe CAP-induced calcium increases in embryonic day 19 rat hippocampal cultures, which included CA1 and CA3 pyramidal cells (data not shown). These results are consistent with our anatomical data and demonstrate that the lack of reporter 
molecule expression parallels what, in our hands, is a functional absence of TRPV1.

\section{Functional TRPV1 expression in} arteriolar SMCs

Unexpectedly, when examining peripheral tissue for PLAP+ axons, we observed discrete, striated staining running in proximity to blood vessels (Fig. $7 A, C, E, F$ ). We found comparable patterns of nlacZ staining (Fig. $7 B, D, G)$, demonstrating that the PLAP derived from TRPV1+ cells that are intrinsic to these tissues. In agreement with this observation, RT-PCR analysis revealed TRPV1 mRNA in cremaster muscle, which has extensive nlacZ+ labeling (Fig. 5J). Furthermore, the nlacZ staining colocalized with immunostaining for $\alpha$-SMA, a filament that is specifically associated with SMCs (Fig. 7D).

The SMC label was not ubiquitous but was concentrated in thermoregulatory tissues, including the cremaster muscle (Fig. $7 A, B$ ), dura (Fig. $7 C$ ), tongue (Fig. $7 D$ ), trachea (Fig. $7 E$ ), skin (Fig. $7 F$ ), and ear (Fig. 7G). In contrast, we found minimal to no SMC labeling in many other organs, including the liver, lung, kidney, pancreas, SC, brain, and aorta. SMC expression was restricted to certain small- to mediumdiameter vessels ( $>100 \mu \mathrm{m}$ in diameter), which, given their size and location, are most likely arterioles. Importantly, the SMC label was substantially reduced after systemic RTX, which kills TRPV1+ cells (Fig. $7 G, H)$. In addition, we saw similar patterns of blood vessel staining in TRPV1 ${ }^{\text {Cre }} / \mathrm{R} 26 \mathrm{R}-$ lacZ mice. (Fig. 7I,J).

As an additional test of the functionality of the TRPV1 expression in SMCs, we performed live-cell calcium imaging (Fig. $8 A-F$ ). Pieces of arteriole were dissected out of the ear and cultured overnight to ensure that any vessel-associated nerves were rendered nonfunctional during imaging. CAP ( 1 and $10 \mu \mathrm{M})$ evoked arteriole constriction that was accompanied by increases in intracellular calcium (Fig. 8C,G,I). Importantly, RR $(10 \mu \mathrm{M})$ reversed the calcium responses (Fig. 8G,I), and neither calcium influx nor constriction was recorded in Trpv1 knockout mice (Fig. $8 D, H, I$ ). We conclude that TRPV1 is functional and mediates vessel constriction in arteriolar SMCs.

\section{Discussion}

\section{TRPV1 in the CNS}

To unequivocally resolve the disagreement as to the extent of TRPV1 expression outside of the primary afferent nociceptor, we used a genetic approach to label TRPV1+ cells with excellent sensitivity and precision. In contrast to previous reports, we conclude that TRPV1 in the CNS is limited to very low-level expression in a few

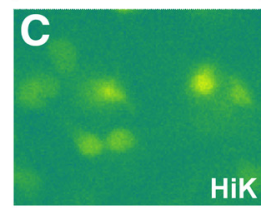

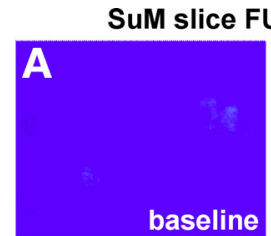
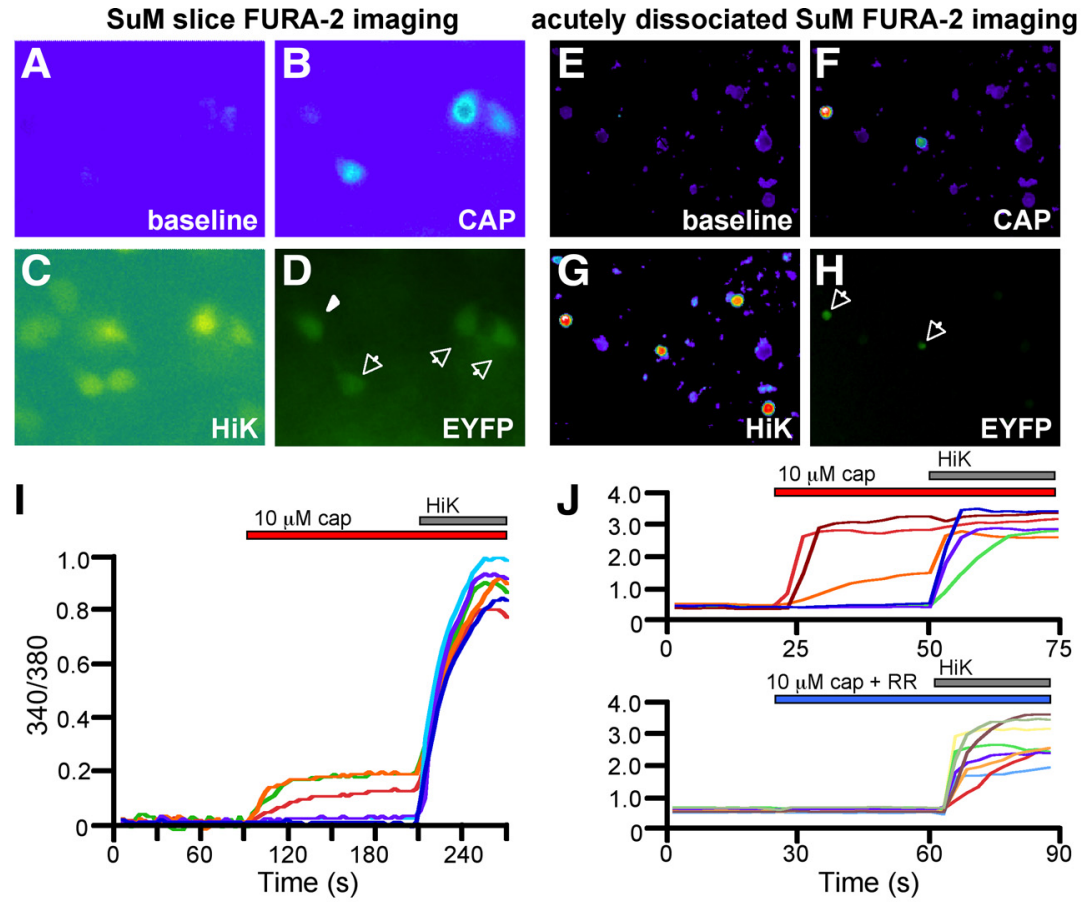

K caudal hypothalamus slice recording

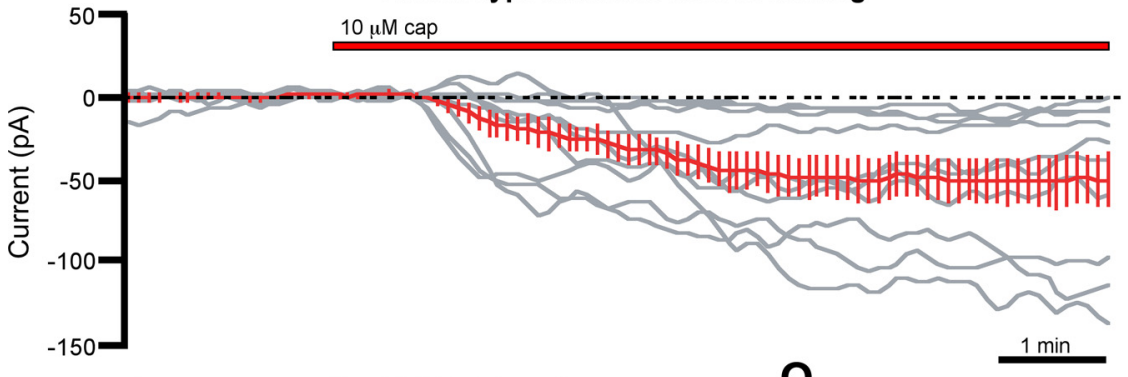

dentate gyrus slice FURA-2 imaging

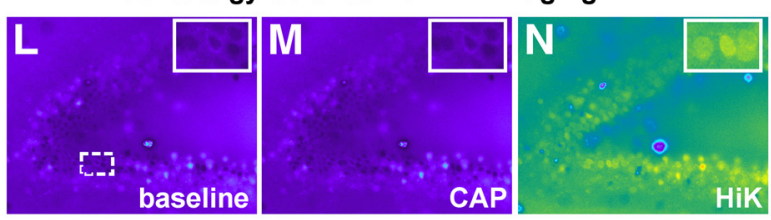

0

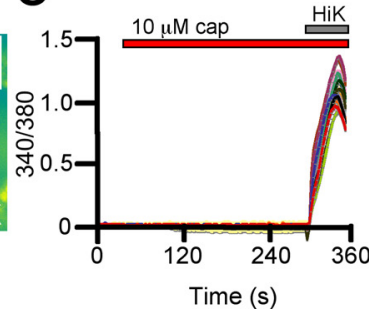

Figure 6. Functional TRPV1 expression in brain regions implicated in the Trpv1 knock-in mice. $\boldsymbol{A}-\boldsymbol{H}$, Calcium imaging of SuM neurons in slices $(\boldsymbol{A}-\boldsymbol{D})$ and acutely dissociated cultures $(\boldsymbol{E}-\boldsymbol{H})$ from TRPV1 ${ }^{\text {(re }} / \mathrm{R}_{2}$ 26R-EYFP mice during application of $10 \mu \mathrm{M} C A P(\boldsymbol{B}, \boldsymbol{F})$ and high $\mathrm{K}^{+}$ ACSF (C, G). $\boldsymbol{D}, \boldsymbol{H}$, Endogenous EYFP fluorescence. $\boldsymbol{I}, \boldsymbol{J}$, Representative $340 / 380$ ratios of the EYFP-positive cells from slices (normalized to baseline; $\boldsymbol{I}$ ) and acutely dissociated neurons ( $(\boldsymbol{)}$ ). Representative $340 / 380$ ratios of cells from another well $(\boldsymbol{J}$, bottom) are shown, demonstrating a block of CAP-induced calcium increases by RR. Arrows in $\boldsymbol{D}$ and $\boldsymbol{H}$ point to CAP-responsive, EYPF + cells; the arrowhead points to EYFP + cell that did not respond to CAP. $\boldsymbol{K}$, Whole-cell recordings of EYFP + SuM cells in brain slices of TRPV1 ${ }^{\text {ree }}$ /R26R-EYFP mice during application of $10 \mu \mathrm{m}$ CAP. The red trace shows the average response of all CAP-responsive cells. $L-N$, Calcium imaging of dentate gyrus neurons in slices during application of $10 \mu \mathrm{M} C A P(M)$ and high $\mathrm{K}^{+} \mathrm{ACSF}(\boldsymbol{M})$. Insets are magnified images of the dashed region in $\boldsymbol{L} . \mathbf{0}$, Representative $340 / 380$ ratios, normalized to baseline, of 30 dentate gyrus neurons during calcium imaging.

discrete brain regions. Most prominent among these is a contiguous band of cells centered along the midline of the posterior hypothalamus and rostral midbrain. We confirmed expression using a number of independent techniques, including RT-PCR, radioactive in situ hybridization, calcium imaging, and slice recording, thus providing multifaceted evidence that nlac $Z$ in these brain areas represents bona fide TRPV1 expression.

We also performed in situ hybridization in rat, primate, and human tissue and found that the restricted expression pattern 

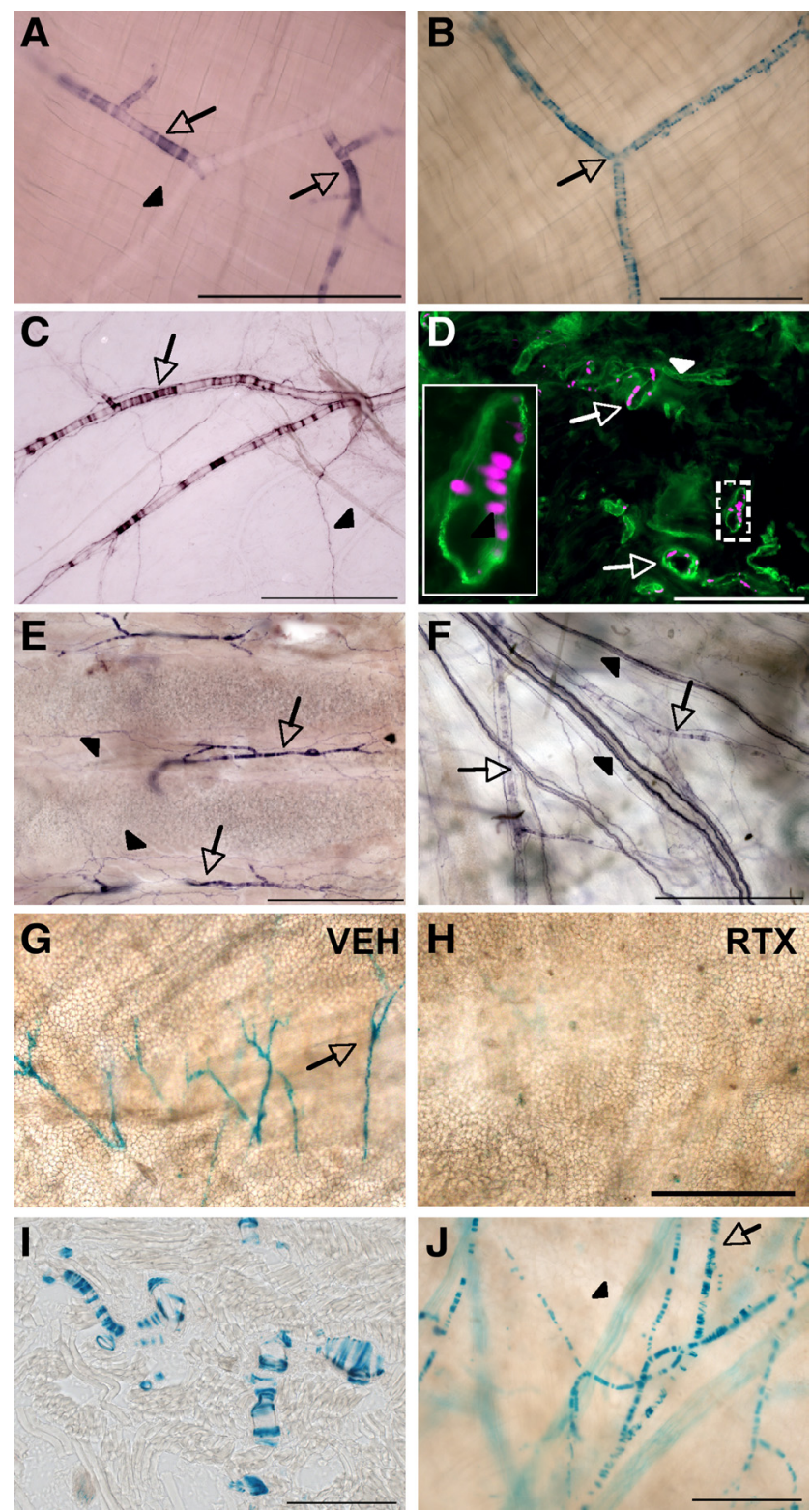

Figure 7. TRPV1 expression in a subset of arteriolar SMCs. $A$, PLAP staining in cremaster muscle, showing PLAP + (arrows) and PLAP - (arrowheads) vessels. $\boldsymbol{B}$, nlacZ staining in cremaster muscle. C, PLAP staining in dura, showing PLAP+ (arrows) and PLAP - (arrowheads) vessels. $\boldsymbol{D}$, nlacZ in tongue (magenta) colocalizes with staining for SMA (green). $\boldsymbol{E}, \boldsymbol{F}$, Inset, Magnification of boxed area. PLAP + SMCs (arrows) were also observed in trachea $(\boldsymbol{E})$ and skin $(\boldsymbol{F})$. Arrowheads point to the PLAP + axonal label, most likely of primary afferent origin. $\boldsymbol{G}, \boldsymbol{H}, \mathrm{RTX}$ eliminates nlacZ staining in the ear. $\boldsymbol{I}, \boldsymbol{J}, \mathrm{A}$ similar pattern of lacZ staining was seen in TRPV ${ }^{\mathrm{Cre}} / \mathrm{R} 26 \mathrm{R}$-lacZ mice. Shown are images from tongue $(I)$ and ear $(J)$. In $J$, the arrow points to lacZ + SMCS, and the arrowhead points to a lacZ + nerve. Scale bars: $\boldsymbol{A}-\boldsymbol{C}, \boldsymbol{E}-\boldsymbol{H}, \boldsymbol{J}, 500 \mu \mathrm{m} ; \boldsymbol{D}, \boldsymbol{I}, 200 \mu \mathrm{m}$.

revealed by the Trpv1 reporter mice was conserved across these species. Notably, the areas of the caudal hypothalamus that have TRPV1+ in situ hybridization signals in both the mouse and rat are the only areas in the rat brain where injection of a high dose of CAP induces cell body degeneration (Ritter and Dinh, 1988), which demonstrates that these signals reflect functional TRPV1 expression in the rat, as we have shown for the mouse. The physiological function of TRPV1 in these brain areas is unclear; however, given the proximity of these regions to the third ventricle, it is possible that TRPV1 could detect changes in CSF temperature.
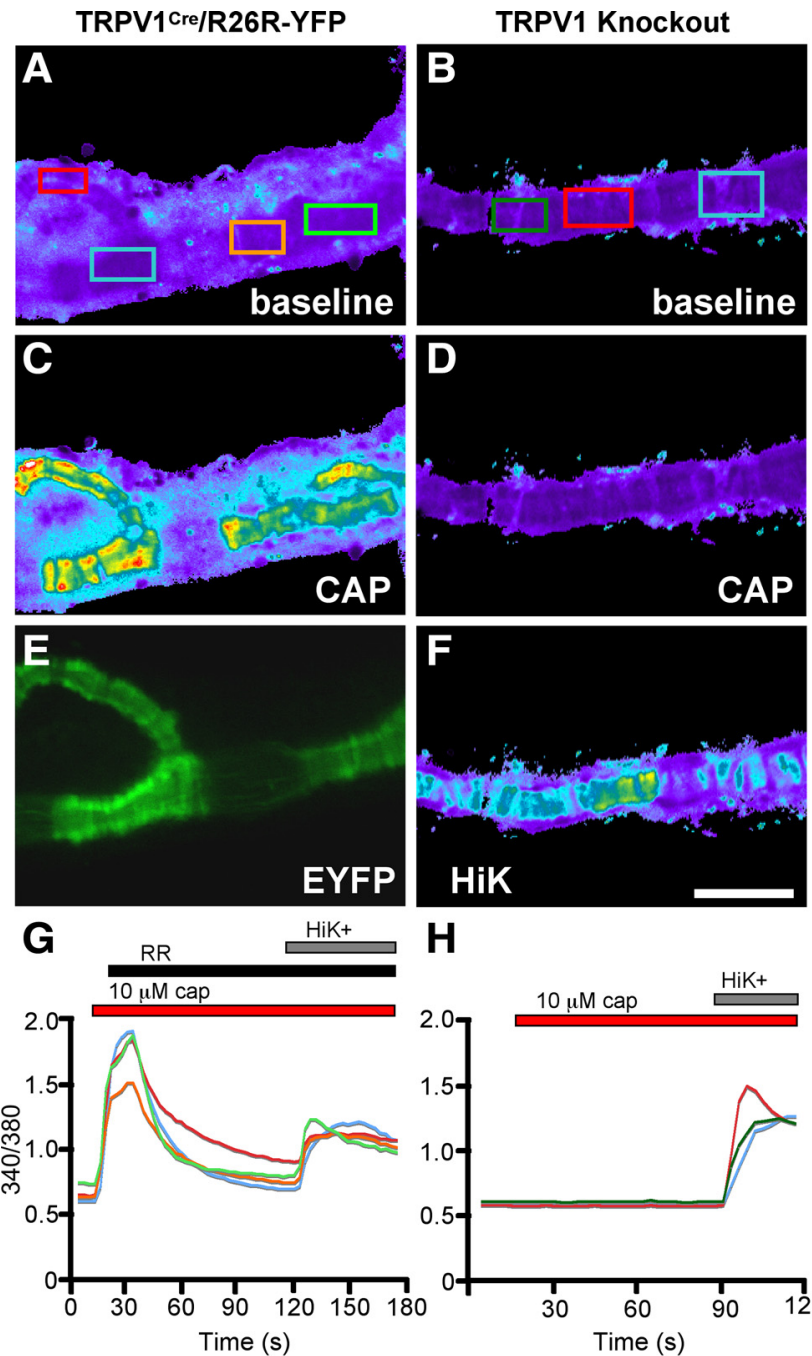

$\mathbf{H}$
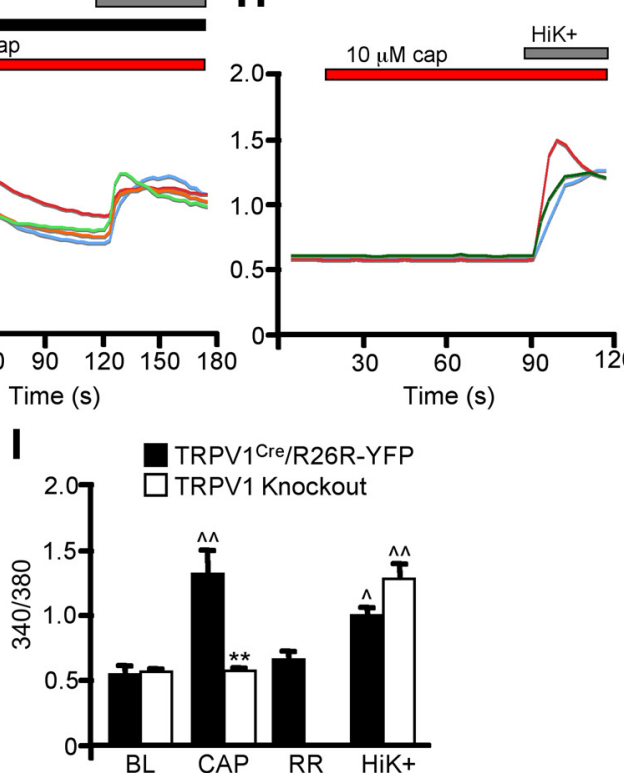

Figure 8. Calcium imaging of TRPV1+ arterioles. $A, C$, Cultured arteriole explants from $\mathrm{TRPV}_{1}{ }^{\mathrm{Cr}} / \mathrm{R} 26 \mathrm{R}$-EYFP mice were imaged with Fura-2-AM dye at baseline (BL) (A) and after stimulation with $10 \mu \mathrm{M}$ CAP (C). E, EYFP expression in arteriolar SMCs of this mouse. $\boldsymbol{B}, \boldsymbol{D}, \boldsymbol{F}$, Explants from Trpv 7 knock-out mice lack CAP responses (D) but maintain responses to HiK (F). G, The $340 / 380$ ratios of boxed regions in $\boldsymbol{A}$. $\boldsymbol{H}$, The $340 / 380$ ratios of boxed regions in $\boldsymbol{B} . \boldsymbol{I}$, Average responses of arterioles from TRPV1 ${ }^{\text {Cre }}$ and Trpv1 knock-out mice after application of CAP, RR, and HiK $(n=4) . \hat{p}<0.05 ;{ }^{\wedge} \hat{p}<0.01$, compared with BL; ${ }^{* *} p<0.01$, compared with $\mathrm{TRPV}_{1}{ }^{\mathrm{Cre}}$; two-way ANOVA with Bonferroni post hoc test. Scale bar, $100 \mu \mathrm{m}$.

Several lines of evidence suggest that TRPV1 is present at extremely low levels in these brain areas. First, we were unable to detect TRPV1 by immunohistochemistry or PLAP staining. Second, we detected only a very faint TRPV1 band with by RT-PCR analysis and needed an extended ( 2 month) exposure period to observe signals with radioactive in situ. Finally, the average currents elicited by CAP in caudal hypothalamic neurons are $\sim 40$ times smaller than those observed in DRG neurons (Caterina et 
al., 2000). Based on the single-channel conductance of TRPV1 at $-60 \mathrm{mV}$ (Tominaga et al., 1998), we estimate that the smallest CAP-induced currents $(-5 \mathrm{pA})$ that we observed in EYFP + cells of the caudal hypothalamus arise from just a few functional channels, highlighting the remarkable sensitivity of the $\operatorname{Tr} p v 1$ knock-in mice.

Several groups used Trpv1 knock-out mice to suggest a functional contribution of this channel outside of the DRG, including urothelial cells of the bladder (Birder et al., 2002), osmosensitive neurons of the supraoptic and paraventricular regions of the hypothalamus (Ciura and Bourque, 2006; Sharif-Naeini et al., 2006, 2008), striatal neurons (Maccarrone et al., 2008), dentate gyrus neurons (Chavez et al., 2010), medium spiny neurons of the nucleus accumbens (Greuter et al., 2010), and hippocampal pyramidal cells (Marsch et al., 2007; Gibson et al., 2008). However, despite using what we consider to be the most sensitive measure yet for detecting TRPV1, our analysis of Trpv1 reporter mice does not support the conclusions of these reports. We did not detect lac $Z$ in any of these cell populations, even in the TRPV 1 Cre/ R26R-lacZ mice, where embryonic expression greatly exceeds that observed in the adult and in which only a few molecules of Cre expression are sufficient to drive recombination. In agreement with the lack of reporter molecule expression, CAP did not elicit calcium increases in either intact hippocampal slices or in cultured hippocampal neurons. Our observations are thus more consistent with studies that found no evidence for TRPV1 in several candidate regions (Kofalvi et al., 2006; Benninger et al., 2008; Taylor et al., 2008; Everaerts et al., 2010).

One caveat is that the use of the internal ribosome entry site in our reporter constructs could have led to spurious reporter molecule expression in areas that lack $\operatorname{Trp} v 1$ transcription, or to artificially low expression in certain brain areas that do express TRPV1. However, given the consistency of our results using multiple independent assays, and across various species, we do not believe this to be the case. It is also possible that our reporters are not expressed in cells that transcribe alternate isoforms of Trpv1 that lack the final exon, although such splice variants have not been reported. Finally, although many of the reports of functional TRPV1 in the brain argue for a postsynaptic localization, some of the phenotypes described in these knock-out papers could reflect a loss of presynaptic TRPV1 that arises from axonal projections of neurons that we demonstrate do express TRPV1. For example, SuM neurons are known to project heavily to the hippocampus (Vertes, 1992).

\section{TRPV1 in arteriolar SMCs}

Classic studies have shown that CAP-evoked release of neuropeptides from the peripheral nociceptor terminals promotes vasodilation. More recently, a direct action of CAP on vascular smooth muscle was reported, but whether this mechanism is widespread or regionally restricted has not been determined (Donnerer and Lembeck, 1982; Duckles, 1986; Kark et al., 2008). Although TRPV1 immunoreactivity has been observed in rat SMCs (Kark et al., 2008) we did not see similar staining in the mouse (data not shown), likely because of high nonspecific antibody staining in peripheral tissues. On the other hand, PLAP and nlacZ provided strong signals in SMCs with minimal background. Importantly, nlacZ staining was reduced in SMCs after systemic RTX injection, confirming functional TRPV1 expression. Finally, calcium imaging of isolated arterioles from the ear showed that genetically marked SMCs respond to CAP application, leading to arteriole constriction. Similar responses could not be evoked in Trpv1 knock-out mice, demonstrating that the direct CAP effects on SMCs require TRPV1.

Interestingly, the SMC labeling was restricted to a subset of arterioles in thermoregulatory tissues, including the tongue, skin, trachea, and cremaster. Whereas activation of TRPV1 on sensory nerve endings leads to local vasodilation, vascular TRPV1 mediates vasoconstriction. Thus, activation of TRPV1 on SMCs could counteract nerve-related changes in vascular tone in response to physiological TRPV1 agonists, such as heat and pH. TRPV1 expression in SMCs may therefore contribute to the thermoregulatory effects induced by TRPV1 antagonists, many of which are being developed to treat chronic pain conditions (Gavva, 2008). On the other hand, the limited TRPV1 expression in the brain indicates that untoward side effects of these drugs are unlikely to be CNS mediated.

\section{References}

Acs G, Palkovits M, Blumberg PM (1996) Specific binding of [3H]resiniferatoxin by human and rat preoptic area, locus ceruleus, medial hypothalamus, reticular formation and ventral thalamus membrane preparations. Life Sci 59:1899-1908.

Benninger F, Freund TF, Hajos N (2008) Control of excitatory synaptic transmission by capsaicin is unaltered in TRPV1 vanilloid receptor knockout mice. Neurochem Int 52:89-94.

Birder LA, Nakamura Y, Kiss S, Nealen ML, Barrick S, Kanai AJ, Wang E, Ruiz G, De Groat WC, Apodaca G, Watkins S, Caterina MJ (2002) Altered urinary bladder function in mice lacking the vanilloid receptor TRPV1. Nat Neurosci 5:856-860

Caterina MJ, Julius D (2001) The vanilloid receptor: a molecular gateway to the pain pathway. Annu Rev Neurosci 24:487-517.

Caterina MJ, Schumacher MA, Tominaga M, Rosen TA, Levine JD, Julius D (1997) The capsaicin receptor: a heat-activated ion channel in the pain pathway. Nature 389:816-824.

Caterina MJ, Leffler A, Malmberg AB, Martin WJ, Trafton J, Petersen-Zeitz KR, Koltzenburg M, Basbaum AI, Julius D (2000) Impaired nociception and pain sensation in mice lacking the capsaicin receptor. Science 288:306-313.

Cavanaugh DJ, Lee H, Lo L, Shields SD, Zylka MJ, Basbaum AI, Anderson DJ (2009) Distinct subsets of unmyelinated primary sensory fibers mediate behavioral responses to noxious thermal and mechanical stimuli. Proc Natl Acad Sci U S A 106:9075-9080.

Chavez AE, Chiu CQ, Castillo PE (2010) TRPV1 activation by endogenous anandamide triggers postsynaptic long term depression in the dentate gyrus. Nat Neurosci 13:1511-1518.

Ciura S, Bourque CW (2006) Transient receptor potential vanilloid 1 is required for intrinsic osmoreception in organum vasculosum lamina terminalis neurons and for normal thirst responses to systemic hyperosmolality. J Neurosci 26:9069-9075.

Cristino L, de Petrocellis L, Pryce G, Baker D, Guglielmotti V, Di Marzo V (2006) Immunohistochemical localization of cannabinoid type 1 and vanilloid transient receptor potential vanilloid type 1 receptors in the mouse brain. Neuroscience 139:1405-1415.

Davis JB, Gray J, Gunthorpe MJ, Hatcher JP, Davey PT, Overend P, Harries MH, Latcham J, Clapham C, Atkinson K, Hughes SA, Rance K, Grau E, Harper AJ, Pugh PL, Rogers DC, Bingham S, Randall A, Sheardown SA (2000) Vanilloid receptor-1 is essential for inflammatory thermal hyperalgesia. Nature 405:183-187.

Donnerer J, Lembeck F (1982) Analysis of the effects of intravenously injected capsaicin in the rat. Naunyn Schmiedebergs Arch Pharmacol 320:54-57.

Duckles SP (1986) Effects of capsaicin on vascular smooth muscle. Naunyn Schmiedebergs Arch Pharmacol 333:59-64.

Everaerts W, Vriens J, Owsianik G, Appendino G, Voets T, De Ridder D, Nilius B (2010) Functional characterization of transient receptor potential channels in mouse urothelial cells. Am J Physiol Renal Physiol 298:F692-F701.

Gavva NR (2008) Body-temperature maintenance as the predominant function of the vanilloid receptor TRPV1. Trends Pharmacol Sci 29:550-557.

Gibson HE, Edwards JG, Page RS, Van Hook MJ, Kauer JA (2008) TRPV1 
channels mediate long-term depression at synapses on hippocampal interneurons. Neuron 57:746-759.

Greuter BA, Brasnjo G, Malenka RC (2010) Postsynaptic TRPV1 triggers cell type-specific long-term depression in the nucleus accumbens. Nat Neurosci 13:1519-1525.

Kark T, Bagi Z, Lizanecz E, Pasztor ET, Erdei N, Czikora A, Papp Z, Edes I, Porszasz R, Toth A (2008) Tissue-specific regulation of microvascular diameter: opposite functional roles of neuronal and smooth muscle located vanilloid receptor-1. Mol Pharmacol 73:1405-1412.

Kobayashi K, Fukuoka T, Obata K, Yamanaka H, Dai Y, Tokunaga A, Noguchi K (2005) Distinct expression of TRPM8, TRPA1, and TRPV1 mRNAs in rat primary afferent neurons with $\mathrm{a} \delta / \mathrm{c}$-fbers and colocalization with trk receptors. J Comp Neurol 493:596-606.

Kofalvi A, Oliveira CR, Cunha RA (2006) Lack of evidence for functional TRPV1 vanilloid receptors in rat hippocampal nerve terminals. Neurosci Lett 403:151-156.

Maccarrone M, Rossi S, Bari M, De Chiara V, Fezza F, Musella A, Gasperi V, Prosperetti C, Bernardi G, Finazzi-Agrò A, Cravatt BF, Centonze D (2008) Anandamide inhibits metabolism and physiological actions of 2-arachidonoylglycerol in the striatum. Nat Neurosci 11:152-159.

Marsch R, Foeller E, Rammes G, Bunck M, Kossl M, Holsboer F, Zieglgansberger W, Landgraf R, Lutz B, Wotjak CT (2007) Reduced anxiety, conditioned fear, and hippocampal long-term potentiation in transient receptor potential vanilloid type 1 receptor-deficient mice. J Neurosci 27:832-839.

Mezey E, Toth ZE, Cortright DN, Arzubi MK, Krause JE, Elde R, Guo A, Blumberg PM, Szallasi A (2000) Distribution of mRNA for vanilloid receptor subtype 1 (VR1), and VR1-like immunoreactivity, in the central nervous system of the rat and human. Proc Natl Acad Sci U S A 97:3655-3660.

Ritter S, Dinh TT (1988) Capsaicin-induced neuronal degeneration: silver impregnation of cells bodies, axons, and terminals in the central nervous system of the adult rat. J Comp Neurol 271:79-90.

Roberts JC, Davis JB, Benham CD (2004) [3H] Resiniferatoxin autoradiography in the CNS of wild-type and TRPV1 null mice defines TRPV1 (VR-1) protein distribution. Brain Res 995:176-183.
Shah NM, Pisapia DJ, Maniatis S, Mendelsohn MM, Nemes A, Axel R (2004) Visualizing sexual dimorphism in the brain. Neuron 43:313-319.

Sharif-Naeini R, Witty MF, Seguela P, Bourque CW (2006) An N-terminal variant of Trpvl channel is required for osmosensory transduction. Nat Neurosci 9:93-98.

Sharif-Naeini R, Ciura S, Bourque CW (2008) TRPV1 gene required for thermosensory transduction and anticipatory secretion from vasopressin neurons during hyperthermia. Neuron 58:179-185.

Soriano P (1999) Generalized lacZ expression with the ROSA26 Cre reporter strain. Nat Genet 21:70-71.

Srinivas S, Watanabe T, Lin CS, William CM, Tanabe Y, Jessell TM, Costantini F (2001) Cre reporter strains produced by targeted insertion of EYFP and ECFP into the ROSA26 locus. BMC Dev Biol 1:4.

Steenland HW, Ko SW, Wu LJ, Zhuo M (2006) Hot receptors in the brain. Mol Pain 2:34.

Szallasi A, Nilsson S, Farkas-Szallasi T, Blumberg PM, Hokfelt T, Lundberg JM (1995) Vanilloid (capsaicin) receptors in the rat: distribution in the brain, regional differences in the spinal cord, axonal transport to the periphery, and depletion by systemic vanilloid treatment. Brain Res 703:175-183.

Taylor AC, McCarthy JJ, Stocker SD (2008) Mice lacking the transient receptor vanilloid potential 1 channel display normal thirst responses and central Fos activation to hypernatremia. Am J Physiol Regul Integr Comp Physiol 294:R1285-R1293.

Tominaga M, Caterina MJ, Malmberg AB, Rosen TA, Gilbert H, Skinner K, Raumann BE, Basbaum AI, Julius D (1998) The cloned capsaicin receptor integrates multiple pain-producing stimuli. Neuron 21:531-543.

Toth A, Boczan J, Kedei N, Lizanecz E, Bagi Z, Papp Z, Edes I, Csiba L, Blumberg PM (2005) Expression and distribution of vanilloid receptor 1 (TRPV1) in the adult rat brain. Brain Res Mol Brain Res 135:162-168.

Vertes RP (1992) PHA-L analysis of projections from the supramammillary nucleus in the rat. J Comp Neurol 326:595-622.

Woodbury CJ, Zwick M, Wang S, Lawson JJ, Caterina MJ, Koltzenburg M, Albers KM, Koerber HR, Davis BM (2004) Nociceptors lacking TRVP1 and TRPV2 have normal heat responses. J Neurosci 24:6410-6415. 